\title{
Diversification as a Corporate Strategy and Its Effect on Firm Performance: A Study of Zimbabwean Listed Conglomerates in the Food and Beverages Sector
}

\author{
Mashiri Eukeria ${ }^{1} \&$ Sebele Favourate ${ }^{2}$ \\ ${ }^{1}$ Midlands State University, Zimbabwe \\ ${ }^{2}$ National University of Science and Technology, Zimbabwe \\ Correspondence: Mashiri Eukeria, Midlands State University, Pox Bag 9055, Gweru, Zimbabwe. E-mail: \\ mashirie@msu.ac.zw
}

Received: January 2, 2014

Accepted: February 9, 2014

Online Published: April 25, 2014

doi:10.5539/ijef.v6n5p182

URL: http://dx.doi.org/10.5539/ijef.v6n5p182

\begin{abstract}
Portfolio diversification in capital markets is an accepted investment strategy. On the other hand corporate diversification has drawn many opponents especially the agency theorists who argue that executives must not diversify on behalf of share holders. Diversification is a strategic option used by many managers to improve their firm's performance. While extensive literature investigates the diversification performance linkage, little agreements exist concerning the nature of this relationship. Both theoretical and empirical disagreements abound as the extensive research has neither reached a consensus nor any interpretable and acceptable findings. This paper looked at diversification as a corporate strategy and its effect on firm performance using Conglomerates in the Food and Beverages Sector listed on the ZSE. The study used a combination of primary and secondary data. Primary data was collected through interviews while secondary data were gathered from financial statements and management accounts. Data was analyzed using SPSS computer package. Three competing models were derived from literature (the linear model, Inverted U model and Intermediate model) and these were empirically assessed and tested.
\end{abstract}

Keywords: diversification, performance, corporate strategy

\section{Introduction}

In the last two decades one of the most popular corporate strategies adopted across the globe has been that of diversification. The phenomenon was popular in the United States and Europe in the late 1960s to 1980s where large corporations sought to expand their empires through acquisitions and mergers. Despite diversification almost becoming a dominant strategy globally, the arguments and questions about the value of this strategic option have never stopped. According to Hitt and Hoskisson (2005), the latest trend across the globe is for companies to disinvest and to concentrate on core businesses. Johnson et al. (2006) suggest that the present trend towards narrower diversification has been driven by a growing preference to gear diversification around creating strong competitive positions in few well selected industries as opposed to scattering corporate investments across many industries. This latest development arose mainly as a result of many companies making strategic mistakes such as making acquisitions in new fields where value is not added to group performance or there are no operating synergies as stated by Dos Santos et al. (2008). The phenomenon has since spread to Zimbabwe as conglomerates have restructured to raise profits and unlock shareholder value.

The research domain that attempts to study the relationship between diversification and performance has not yet reached definitive and interpretable findings to determine whether diversification strategy creates or destroys value despite the substantial number of empirical studies (Santalo \& Beccera, 2008). In finance, the case for diversification is anchored in Markowitz's portfolio theory that risk is reduced by adding to the portfolio, assets with unrelated cash flows or returns. Other researchers like Shliefer and Vishny (2006) have argued that while investors should diversify, firms should not unless synergies can be exploited. Thus, it appears that diversification may be a bad strategy in the long run unless the various businesses in the corporate portfolio can obtain certain synergies and gain competitive advantage (Collins \& Montgomery, 2008). The agency theory says that managers can pursue their own interests through diversification which are not always in line with their 
shareholders. This complicates the case for diversification. It raises the debate of whom between the investor and corporate executive should diversify.

According to Thompson and Strickland (2006), "Diversification is a collection of individual businesses." Diversification also allows companies to compete in an array of different businesses that may or may not be related. Two seemingly irreconcilable facts motivate this study, one diversification continues to be an important strategy for corporate growth in the world over, Africa and in Zimbabwe and two while Management and Marketing disciplines favour related diversification, Finance makes a strong case against corporate diversification as pointed out by Brealey and Myers (2007, p. 946) when they argue that "diversification is easier and cheaper for the stockholder than for the corporation".

Since the late 1990s and the early 2000s the desire for repositioning prompted listed companies in Zimbabwe like Delta, TA holdings and Innscor Africa to adopt diversification as a corporate strategy leading to the birth of Zimbabwean conglomerates. Now, diversification especially conglomeration has become a popular practice for Zimbabwe's firms to grow with the likes of Econet being the recent culprits acquiring TN Bank. The research sought to establish why companies like Innscor Africa Limited and Delta corporation used diversification as a corporate strategy, when finance scholars such as Barney (2006) argue that "companies should stick to their core competencies" suggesting that investors should diversify on their own and why some of them later unbundled, with the likes of Delta corporation spinning four of its subsidiaries around 2001 which included OK Zimbabwe, Pelhams and Zimsun hotels. The company later on went to acquire $29.8 \%$ of listed African Distillers, a related industry firm and then later $41.9 \%$ of listed Ariston Holdings- an unrelated business with interests in agriculture, http://www.zimbabwe-stock-exchange.com/listed-company/dlta/ (22/08/13:14:00).

Was the unbundling motivated by the costs of diversification exceeding the benefits, was it necessitated by a reduction in corporate performance (conglomerate discount as described by Ozbas and Scharfstein (2010) or some other factors? In making further acquisitions after unbundling, were the executives recreating the old empire or safeguarding shareholders interests by diversifying? What impact did these strategies have on corporate performance and shareholder value? The study sought to identify all forms of diversification employed by these conglomerates and evaluate their effects on firm performance.

\section{Literature Review}

\subsection{Introduction}

There is still disagreement as to whether diversification increases or reduces performance, whether it causes a conglomerate premium or a discount respectively. The relationship is still controversial, contradictory and inconclusive. Questions still persist as to whether diversification strategy is universally profitable or universally unprofitable. Thus the issue whether diversification improves or worsens firm performance is still worthy of further research such as the one undertaken in this study. Besides, very little exists in terms of research in the area of diversification and its impact on firm performance in Africa in general and Zimbabwe in particular. The study sought to investigate diversification as a corporate strategy and examining the relationship between diversification strategy and firm performance using Zimbabwean conglomerates in the food and beverages sector by asking a question initially posed by Villalonga (2004a) on the effect of diversification on firm performance, Diversification discount or premium? In the words of Santalo and Becerra (2009), the diversificationperformance linkage is worthy of research since value creation has been put at the top of the objectives which should guide firm strategy.

It is accepted that in developed economies investors can independently diversify their portfolios because more efficient capital markets exist. As this is not the case in most of African states, the understanding of how internal capital markets of diversified firms work is very important for policy makers as this would also assist them deter anti-competitive practices by big firms.

\subsection{When to Diversify and Motives for Diversifying?}

\subsubsection{The Concept of Diversification}

The concept of diversification is yet to be clearly defined and there is no consensus on the precise definition among researchers. Apart from the definitions by scholars like (Turner, 2005; Thompson \& Strickland, 2006; Aggarwal \& Samwick, 2003), Johnson et al. (2006) says it's a collection of businesses under one corporate umbrella. Lending support to all the various definitions, for this research diversification is defined in a broad sense as expanding business fields either to new markets, new products or both while retaining strong core businesses.

Santalo and Becerra (2008) allude to the fact that a company can diversify when its cash flows become 
increasingly uncertain. Turner (2005) suggests that when the core business no longer offers the investor the acceptable returns for the risk taken, there is need to diversify. In the words of Barney (2006) if the core business no longer offers growth opportunities, room for increasing sales and profitability then business should diversify.

\subsection{Diversification Strategies}

Diversification strategies are used to expand the firm's operations by adding markets, products, services or stages or production to the existing business. Kotler (2006) identifies three types of diversification strategies namely, concentric, horizontal and conglomerate. "Horizontal Diversification strategy" occurs where a company seeks new products that could appeal to its current customers even though the new products are technologically unrelated. "Conglomerate Diversification Strategy" takes place where a company seeks new businesses that have no relationship with their present business or market operations (Thompson \& Strickland, 2006).

Collins and Montgomery (2005) divided diversification into two types related and unrelated diversification. The two are analyzed in-depth, considering their merits and demerits whereas Emms and Kale (2006) describes the various ways and strategies adopted by diversifying companies as modes of diversification.

Collins and Montgomery (2008) believe that related diversification involves building shareholder value by capturing cross business strategic fits. The combining of resources creates new competitive strengths and capabilities (BCG, 2006). Related diversification may involve use of common sales force to call on customers, advertising related products together, use of same brand names and joint delivery. On the other hand, Thompson and Strickland (2006) believe that many companies decide to diversify into any industry or business that has good profit opportunities. Johnson et al. (2006) noted that in most cases companies that pursue unrelated diversification nearly always enter new businesses by acquiring an established company rather than by forming a start up subsidiary. The basis for this strategy is that, growth by acquisition translates into enhanced shareholder value faster and the payback period is quicker.

\subsection{Risks and Rewards of Diversification as a Strategy}

The corporate managers bring both a cost to the combined organizations as well as the opportunity to manage the combined resources of the different businesses (Wan, 2011). According to Collins \& Montgomery (2005), a more meaningful approach is to analyse the costs (risks) and benefits (rewards) under the strategies of related and unrelated diversification.

Hoechle et al. (2009) argues that the major advantages of related diversification are that it leads to operational synergies, which in turn develop into long-term competitive advantage. Johnson et al. (2006) argue that most of the advantages of related diversification stem from the fact that it allows the company to enjoy economies of scope. Despite the above advantages related diversification can still fail to reap the originally predicted returns and benefits due to several shortcomings and demerits. Gary (2005) allude to the fact that related diversification analysis at times underestimates the softer issues like change management, and may tend to overestimate synergistic gains.

The Boston Consulting Group (BCG) (2006), have noted that business risk is scattered over a set of diverse industries and one can spread risk by spreading businesses with totally different technologies, competitive forces, market features and customer bases. This in line with the Markowitz portfolio theory in finance which suggests that diversification reduces a firm's exposure to cyclical and seasonal uncertainties and risks. Dos Santos et al. (2008) also pointed out that a company's financial resources can be employed to maximum advantage by investing in whatever businesses offering the best profit prospects.

Campbell, Goold and Alexander (2006) identify that there is a big demand on corporate level management to make sound decisions regarding fundamentally different businesses operating in different industries and competitive environments. This is often difficult to achieve where skills are not readily available which is true of the current Zimbabwean "brain drain" phenomenon. This was also echoed by Pindyck and Rubinfeld (2005). On the same line of thought Shliefer and Vishny (2006) argue that corporate managers have to be shrewd and talented to run many different businesses.

\subsection{The Diversification- Performance Relationship}

The effect of corporate diversification on firm performance has been widely studied (Dimitrov \& Tice, 2006; Yan et al., 2010; Hoechle et al., 2009; Hoskisson \& Peng, 2005; Wan, 2011; Wright et al., 2005 and others). While this topic is rich in studies many researchers concurred on the lack of consensus on the precise nature of the relationship between diversification and firm performance. Some studies have shown that diversification improves profitability over time citing a positive relationship (Yan et al., 2010; Hoskisson \& Peng, 2005; Wan, 2011), whereas others have demonstrated negative relationship and that diversification decreases performance 
(Ozbas \& Scharsfstein, 2010; Maksmovic \& Phillip, 2007). Still others have shown that diversification and performance linkage depends on business cycle. Santalo and Becerra (2004) explain conceptually and provide empirical evidence that no relationship exists (positive, negative or even quadratic) between diversification and firm performance.

Santalo and Becerra (2008), concurring with Stowe and Xing (2006), broadly conclude, (a) the empirical evidence is inconclusive (b) models perspectives and results differ based on the disciplinary perspective chosen by the researcher and (c) the relationship between diversification and performance is complex and is affected by intervening and contingent variables such as related versus unrelated diversification, and mode of diversification.

In the words of Daud, Salamudin and Ahmad (2009), studies in the areas have tended to provide inconclusive results due to inconsistent data, different time frames, different performance measures and moderate variables. Mackey (2006) argues that the contradictory results are related to; different timeframes, various measures of profitability and different measures of diversification. Andreou and Louca (2010) assert that the confusion is partly methodological and partly theoretical. However, the diversification- performance puzzle was summarized in the theoretical models outlined below as the theoretical framework is reviewed.

\subsection{Diversification and Shareholder Value}

The impact of diversification on shareholder value is mixed. Academics, consultants, the public and financial community have different views. Some studies such as (Villalonga, 2004a, 2004b; Dos Santos, 2008; Doukas \& Kan, 2006; Santalo \& Becerra, 2008) have been aimed at establishing whether diversification leads to shareholder value destruction or improvement that is, either creating a discount or a premium. Some studies have proved that high levels of diversification increase profitability and shareholder value (Dimitrov \& Tice, 2006; Yan et al., 2010; Kuppuswamy \& Villalonga, 2010). Villalonga (2004b) estimated the value effect of diversification by matching diversifying and single segment firms on their propensity score and found out that diversification does not destroy shareholder value. In the same direction Doukas and Kan (2006) pointed out that segments acquired by diversifying firms in most cases already traded at a discount before acquisition and hence their acquisition will improve performance, thus refuting the post acquisition negative relationship between diversification and performance in terms of profitability and shareholder value. Others have also shown that high levels of diversification are detrimental to profitability and on average destroy shareholder value for diversifiers pointing to the fact that refocusing generates positive shareholder returns. (Tongli et al., 2005). Masulis et al. (2007) found that firm characteristics which make firms diversify might also cause them to be discounted.

\subsubsection{Corporate Diversification Destroys Shareholder Value}

There is a school of thought among academic researchers, consultants, and investment bankers that diversified firms destroy value (Ozbas \& Scharfstein, 2010; Hoechle et al., 2009). The evidence that supports this conclusion comes from a variety of sources. Diversified firms tend to have a lower Tobin's Q; they trade at a discount of up to $15 \%$, when compared to the value of a portfolio of stand-alone firms; they face an increased likelihood of being broken up through reorganization that varies directly with the size of the discount; and the stock market tends to react favourably to increases in refocus (Collins \& Montgomery, 2008; Masulis et al., 2007; Doukas \& Kan 2006; Stulz et al., 2007). In line with this school of thought Breadley et al argue that companies should stick to their core competencies and let shareholders diversify on their own as diversification is costly rather than beneficial for the corporation. The author states that poor multidivisional performance destroys value. Doukas and Kan (2006), point out the problem of capital misallocation in diversified firms as the one of the reasons for poor performance.

\subsubsection{Corporate Diversification Creates Shareholder Value}

Despite researchers like Ozbas and Scharfstein (2010) concluding that diversification is not a successful path to higher performance because the value of the diversified firm is less than the sum by an average discount factor of 13-15\%, others like Akbulut and Matsusaka (2010), Kuppuswamy and Villalonga (2010), Dastidar (2009) argue against the diversification discount and point to a premium. The researchers found empirical evidence that diversification might be a value enhancing strategy. Dimitrov and Tice (2006) assert that there is no diversification discount and in fact diversified firms trade at a significant premium.

In the words of Yan et al. (2009), "corporate diversification becomes more efficient and value adding where capital markets are relatively inefficient and various segments of a diversified firm would be financially constrained as single segments hence diversified firms would create shareholder value as compared to single segments". Kuppuswamy and Villalonga (2010) find that relative value of diversified firms increase significantly. Akbulut and Matsusaka (2010) concur when they point out that stock markets react positively to diversifying 
acquisitions. Dos Santos et al. (2008) found evidence that US acquirer firms increase in value in the two years surrounding the acquisition. Kiymaz (2006) found that both divesting and acquiring firms experience a statistically significant wealth gains during sell off announcements. Santalo and Becerra (2008) argue that the effects of diversification on firm performance are not homogenous but rather heterogenous across industries. Diversified firms might be valued at a discount in some industries, but trade at a premium in others.

Finally, recent works (Stowe \& Xing, 2006; Emms \& Kale, 2006; Kuppuswamy \& Villalonga, 2010) have attempted to overcome such a discount/premium dichotomy and have come up with existence of moderating variables in the diversification-value relationship which can make some diversifiers create more value than others. Does diversification create value for firms? The answer here would seem to "it depends". It is observed that, even though discount seems to prevail in conglomerates, there are some cases where premiums are found (Santalo \& Beccera 2008). As a consequence the debate has recently centered on seeking conditions under which diversification can result in a value-creating strategy (Mackey, 2012). In this vein, different moderating variables have been suggested, such as relatedness between segments, industry, period of analysis, geographical versus industrial diversification, diversity of growth opportunities or the diversification profile (Santalo \& Becerra, 2008; Andreou \& Louca, 2010; Stowe \& Xing, 2006).

To summarize the above arguments on the diversification- value puzzle, on the positive side (value creation) diversified firms benefit more than single segment firms from an efficient internal capital market, from cheaper access to external sources of funds. In addition diversified firms follow a neoclassic value maximization model, searching for new growth opportunities, maximizing synergies across businesses, acquiring poor performing firms and improving the productivity of target companies through higher management capabilities. On the negative side (value destruction), empirical findings have shown its drawbacks, especially driven by agency arguments that divert funds from their best uses, by development of business segments lacking in potential synergies or because the firm is too big and becomes unmanageable.

\section{Research Methodology}

The study focused on the listed conglomerates in the food and beverages sector with operations in the ZSE. The study was limited to the period spanning 1999-2004, a six-year span that should be adequate in terms of following strategies and identifying trends. A shorter time span is desirable because strategic plans change overtime. A cross-sectional design was used and involves measuring a phenomenon at a point in time (Herrman, 2009). Short period surveys conducted by previous researchers among others (Daud et al., 2009; Syed \& Rao, 2004) ranged from 4 to 6years. The justification being that, firms rarely maintain the same strategy over a long period of time. The period was also chosen for comparability of financial information purposes as it spans the period before the currency crisis deepened to witness the constant dropping of the zeros in the currency. This was also the time when these conglomerates diversified extensively.

Currently there are five companies in the food and beverages sector namely Delta Corporation, Innscor Africa, Dairiboard Zimbabwe, Colcom Holdings and National Foods (with the last two being subsidiaries of Innscor Africa). The last two were eliminated on the basis that they are part of Innscor and Dairiboard Zimbabwe was also eliminated because from 1997 the time it listed up to 2006 it was a focused company effectively leaving two companies that were considered representative of the conglomerates in the sector. Senior executives in the companies were the target population for interviews. The study used judgmental sampling for the in depth interviews by selecting 12 executives for the two groups and there was a $100 \%$ response rate.

Secondary data sources included published accounts, minutes of strategic meetings and board meetings, management accounts, monthly financial reports, internal audit reports and segment reports. The principal sources were Audited Annual Reports for the two companies. A number of artifacts and documentary sources were collected during the data gathering stage. These included Delta and Innscor publications, the Groups' public websites http://www.delta.co.zw/ (07/09/13:15:40) and www.innscorafrica.com/inn-Zimbabwe.html (07/09/13:16.04) respectively.

\subsection{Measurement of Variables (Diversification and Performance)}

Empirical studies on diversification and performance have used different measures to measure these two variables, diversification and performance (Santalo \& Becerra, 2008; Dimitrov \& Tice, 2006; Ozbas \& Scharfstein, 2010). The study adopted some of these measures which have been successfully used by the previous researchers justifying the measurement methods used citing some of the reasons and suggestions made by previous researchers. 


\subsection{Diversification (Specialisation Ratio)}

For this study Rumelt's Specialization Ratio was adopted and used. The study sought to classify the conglomerates into one of the three categories identified by Yan et al. (2009). The study used the data gathered on sales to classify the Company. For all the ten years under study the study sought to measure the average sales from the company's dominant business to see whether they are above $95 \%$ of total sales, lie between $95 \%$ and $70 \%$ of its total sales or fall below the $70 \%$ mark. This measure of diversification was adopted because of its advantages of easier calculation and understandability. Splitting diversification into related and unrelated diversification as advocated for by the entropy measure is cumbersome and difficult to calculate.

Yan et al. (2009) and Daud et al. (2009) used the Specialization Ratio (SR) to classify firms into three classes of diversification. Its logic reflects the importance of the firm's core product market to that of the rest of the firm.

Operationally, SR is a ratio of the firm's annual revenues from its largest discrete, product market activity to its total revenues. In the diversification literature, S.R has been one of the methods of choice for measuring diversification. It is easy to understand and calculate.

The Rumelt's Specialization ratio categorized companies as shown in Table 1 below:

Table 1. Specialisation ratio

\begin{tabular}{ll}
\hline SR Values & \\
\hline Undiversified, Single Product Firms & $\mathrm{SR} \geq 0.95$ \\
Moderately Diversified Firms & $0.95<\mathrm{SR} \leq 0.7$ \\
Highly Diversified Firms & $\mathrm{SR}<0.7$ \\
\hline
\end{tabular}

Daud et al. (2009) Classified firms into three groups (1) Single product firms with SR $>0.95$; (2) moderately diversified firms with $\mathrm{SR}$ values between $0,95<\mathrm{SR}<0.7$. This group includes dominant, relatedly diversified and unrelatedly diversified firms (3) the highly diversified category of firms have $\mathrm{SR}<0.7$ and include conglomerates, relatedly constrained and relatedly linked firms. Yan et al. (2010) calls a firm moderately diversified if its sales from its dominant business lies between $95 \%$ and $70 \%$ of its total sales and he calls a firm highly diversified if the sales from its dominant business is below the $70 \%$ mark.

\subsection{Performance}

For the purpose of this research, key performance indicators such as turnover (sales), net profit, net assets, earnings per share, dividend per share and market price per share were analyzed to measure performance. Borrowing from Tongli etal (2005) and Daud et al. (2009), return on assets (ROA) and return on sales (ROS) were used to measure performance (especially as regards to profitability). Earnings per share, dividend per share and market price per share were used to address the effect of diversification on shareholder value together with market return. Daud et al. (2009)'s calculation of market return was adopted. Return on Assets is defined as net Income (Income available to ordinary shareholders divided by the book value of total assets.

$$
\text { Return on Assets }(\mathrm{ROA})=\frac{\text { Net Income after taxes but before extra ordinary items }}{\text { Total Assets }}
$$

To complement ROA, Daud et al. (2009) also like Tongli et al. (2005) used Market return as a proxy for market performance and this was calculated as share return and for this study Daud's calculation of market return (share return) was adopted as shown below.

$$
\text { Share return }=\frac{S P n-S p i \times 100}{S p i}
$$

Share return $=$ percentage Change of Share price over initial value;

$\mathrm{SPi}=$ Beginning of Year Share price;

$\mathrm{SPn}=$ End of Year Share Price.

Stowe and Xing (2006) argued that the use of different accounting measures of performance has led to ambiguous results since these are subject to manipulation prompting the authors to also adopt market measures as alternative proxy. Even though both measures may have limited capability to measure performance (accounting and market measures) at least using them together could capture almost all performance goals. According to Tongli et al. (2005), a single measure that satisfies all performance criteria is not available and multiple measures may be appropriate to establish the robustness of findings. Therefore the authors found it necessary to incorporate different measures to examine diversification and performance relationship. 
Since accounting conventions make these variables unreliable, financial economists prefer market returns or discounted cash flows as performance measures. For consistency purposes Stowe and Xing (2006) used two accounting measures, ROE and ROA along with market return to measure performance. Daud et al. (2009) employed accounting measure of performance by using return on asset (ROA) as a proxy. According to Santalo and Becerra (2008), this ratio is under management control, even though it is used by practitioners and academics because it controls for differences in a firm's financial design and also because investors make investment decisions based on accounting numbers as better financial results lead to higher share prices. When assessing diversification- performance in India, Palepu (2009) used the same ratio.

Developing from previous studies as outlined above the study used accounting based measures, complementing these with market based measures such as share return as earlier mentioned to reduce the limitations of accounting based measures and for consistency with the works of previous researchers who argued that combining the two enhances reliability and validity of results. SPSS computer package was used to analyze some of the data and the findings are as follows.

\section{Results}

\subsection{Effects of Diversification on Performance (Turnover, Profits, EPS, DPS)}

This section focuses on the traditional economic measures used to analyze and examine company performance. The analysis covers an analysis of turnover, net profit before and after tax, earnings per share, net assets analysis, market price per share, ROA, ROS and a performance by sector analysis. The performance by sector analysis enables the reader to ascertain what the major contributors towards group profitability are and their direct link to the diversification strategies used.

According to Daud et al. (2009), turnover represents total sales of merchandise or services sold to customers. It indicates the level of business made in any one period. The performance of the individual groups that is Delta and Innscor is shown below in table 2.

Table 2. Average yearly turnover

\begin{tabular}{lll}
\hline Year & Value- \$m's & \%Growth \\
\hline 1999 & 7,261 & \\
2000 & 10,995 & 51.43 \\
2001 & 17,953 & 63.28 \\
2002 & 40,001 & 122.8 \\
2003 & 120.166 & 200.58 \\
2004 & 577,444 & 381.61 \\
\hline
\end{tabular}

Table 2 above shows that there is a positive and linear relationship between diversification and firm performance as measured by turnover.

\subsection{Net Profit Before Tax Analysis 1999-2004}

According to Tongli et al. (2005), net profit before tax shows the overall profitability of the company resulting from business activities. It is profit attributable before taxes are paid over to government. It is a measure of how attractive the business is. Once again this can only be attributable to a successful diversification strategy considering most acquisitions were done in the early 2000s. Indeed diversification is positively and linearly related to performance as shown by figureses in Table 3 below.

Table 3. Average yearly net profit before tax

\begin{tabular}{lll}
\hline Year & Value- \$m's & \%Growth \\
\hline 1999 & 471 & \\
2000 & 641 & 36.1 \\
2001 & 1,233 & 92.36 \\
2002 & 2,746 & 122.71 \\
2003 & 23,915 & 770.09 \\
2004 & 153,781 & 599.95 \\
\hline
\end{tabular}


Table 3 shows a growth in average net profits for the 6 years, this is in line with the growth in the net profits before tax of the 2 groups.

\subsection{Earnings per Share (EPS) Analysis 1999-2004}

According to the Brealey et al. (2007) earnings per share (EPS) is one of most widely used statistics employed by financial analysis. It is particularly useful in comparing profitability of enterprises over time. The ratio is an expression of earnings attributable in cents divided by average number of shares. This shows an increase in earnings per share for the 6 years per each group. This growth could be attributable to the growth in earnings due to the benefits of diversification. Table 4 below outlines the average EPS between 1999 and 2004 .

Table 4. Average Earnings per Share (EPS) analysis 1999-2004

\begin{tabular}{lll}
\hline Year & Value- Cents & \%Growth \\
\hline 1999 & 57 & \\
2000 & 77 & 35.08 \\
2001 & 148 & 92.2 \\
2002 & 472 & 218.92 \\
2003 & 2.844 & 502.54 \\
2004 & 17.018 & 498.38 \\
\hline
\end{tabular}

A review of the Average EPS indicates a steady performance by the conglomerates ultimately leading to an increase in shareholder value.

4.4 Dividend per Share (DPS) Analysis 1999-2004

Everingham and Hopkins (2005) view dividends per share (DPS) as another useful statistic employed by financial analysis. It is particularly useful in comparing dividends paid to investors of the business over time against other enterprises. The ratio is an expression of dividends in cents divided by average number of shares. Table 5 below shows Average DPS between 1999 and 2004 for the 2 companies.

Table 5. Average DPS analysis 1999-2004

\begin{tabular}{lll}
\hline Year & Value- Cents & \%Growth \\
\hline 1999 & 220 & \\
2000 & 66 & 0 \\
2001 & 800 & 0 \\
2002 & 2,410 & 1112 \\
2003 & 25,350 & 201.25 \\
2004 & $1,300,000$ & 5028.34 \\
\hline
\end{tabular}

Source: Innscor and Delta's Annual Reports.

Table 5 above shows an average growth in dividend per share from 220 cents from 1999 to 1300000 cents in 2004. This is in agreement with the individual company DPS. Dividend per share is a measure of shareholder value and therefore for the years 2002 to 2004 the shareholders are earning a substantial return on their investment. This is in line with the arguments by Kuppswang and Villalonga (2010) who argued in support of diversification creating shareholder value.

\subsection{Net Assets Analysis 1999-2004}

This ratio is not frequently used by many companies. It represents the total value of assets as a percentage of total number of shares issued (Stowe \& Xing 2006). The ratio shows the value of assets owned by the company per share. Ideally this shows potential investors how the company is growing in terms of assets. An analysis of Average Net Assets from 1999 and 2004 for the two groups is shown in Table 6 below: 
Table 6. Average net assets analysis 1999-2004

\begin{tabular}{lll}
\hline Year & Value- Cents & \%Growth \\
\hline 1999 & 450 & \\
2000 & 664 & 48 \\
2001 & 1,062 & 60 \\
2002 & 2,217 & 108.75 \\
2003 & 13,680 & 517.05 \\
2004 & 82,616 & 503.91 \\
\hline
\end{tabular}

Source: Innscor and Delta's Annual Reports.

From table 6 above, it was noted that average assets grew from $\$ 450$ million in 1999 to $\$ 83$ billion in 2004. This reflects the growth in net assets for the individual companies (Innscor's net assets grew from $\$ 467$ million in 1999 to $\$ 150$ billion in 2004 and Delta's assets grew from $\$ 433$ million to $\$ 15$ billion). This could be attributed to the acquisitions made during this period for example Innscor increases its share holding in National Foods and Colcom around 2003 and Delta acquires Dawning Properties around the same period.

Return on assets and return on sales

The return on sales and return on assets point to a positive linear diversification-performance linkage. In this case as the conglomerates acquire more businesses between 2000 and 2004 performance improves tremendously as shown below.

There was a tremendous growth in the 2 ratios from $32 \%$ to $80 \%$ and $30 \%$ to $47.5 \%$ for ROS and ROA respectively from 1999 to 2004 . This could be attributable to the growth in net profits due to the benefits of diversification and also due to the hyperinflationary environment that prevailed in Zimbabwe at that time. The above findings could be graphically presented depicted by table 7 below:

Table 7. Yearly ROS and ROA

\begin{tabular}{lll}
\hline Year & ROS \% & ROA \% \\
\hline 1999 & 32 & 30 \\
2000 & 34 & 35 \\
2001 & 38 & 40 \\
2002 & 75 & 43 \\
2003 & 82 & 45 \\
2004 & 80 & 47.5 \\
\hline
\end{tabular}

Source: Delta and Innscor Annual Reports.

The above table shows a positive and linear growth in the 2 ratios for the years 1999 to 2004. This is in line with the arguments by Palich et al. (2000) who suggested the linear model of the diversification-performance relationship. As the groups acquired different companies in the early 2000s performance as measured by the 2 ratios continuously increased.

\subsection{Market Price per Share Analysis 1999-2004}

Schliefer and Vishny (2006) view market price per share as the price that a willing seller and willing buyer are agreeable to trade. Since the conglomerates are listed on the stock exchange it is the quoted price for the share. Daud et al. (2009) views this as the best measure for firm performance especially shareholder value since it is the price determined by market perceptions and management have no control over. The authors also recommend market return as a measure of firm performance. Tabled in 8 below are the average market prices per share from 1999 to 2004. 
Table 8. Market price per share analysis 1999-2004

\begin{tabular}{lll}
\hline Year & Value- Cents & \%Growth \\
\hline 1999 & 97.77 & \\
2000 & 95.015 & 2.81 \\
2001 & 212.505 & 123.65 \\
2002 & 715.03 & 236.4 \\
2003 & $2,249,410$ & 214.59 \\
2004 & $58,009,980$ & 2.478 .89 \\
\hline
\end{tabular}

The high average share price in 2004 was primarily attributable mainly to the Bull Run experienced on the ZSE during this period. It was also a result of positive financial results, positive assets growth, high dividend payouts and an aggressive diversification strategy. The percentage growth according to Daud et al. (2009) is the share return (see chapter three for calculation of share return). The spread of returns clearly shows the positive contribution the diversification strategy has had on the groups' results. The conglomerates managed to successfully combine both related and unrelated units in order to improve their turnovers, gross profits, net profits, assets base, and earnings per share, dividend per share and market price per share.

\subsection{Multiple Linear Regression Analysis}

Multiple linear regression was used in order to check on the relationship between growth (as it was assumed that it was due to diversification considering that there was tremendous growth between 2000 and 2004, the period when most acquisitions were made) and the other factors which include earnings per share (EPS), net profit (NP), return on assets (ROA) and return on sales (ROS). Statistical Package for Social Scientists (SPSS) was used in the analysis of the data and the results found were as shown in Table 9 below:

Table 9. Model summary ${ }^{\mathrm{a}}$

a: Predictors: (Constant), ROS, ROA, NP, EPS.

\begin{tabular}{ccccc}
\hline Model & R & R Square & Adjusted R Square & Std. Error of the Estimate \\
\hline 1 & $.672^{\mathrm{a}}$ & 0.451 & 0.36 & 26.03316 \\
\hline
\end{tabular}

The correlation (under the R) is .672. Thus, there is a positive, correlation between growth and the independent variables which are ROS, ROA, NP and EPS. The table shows that about $36 \%$ of the change in growth was determined by the independent variables.

An Analysis of Variance (ANOVA) was done in order to check on the significance of the model.

Relationship testing:

H0: The coefficients are equal to zero i.e. they are not significant;

H1: The coefficients are different from zero, i.e. they are significant;

The results are shown in Table 10 below:

Table 10. ANOVA ${ }^{\mathrm{b}}$

\begin{tabular}{llllll}
\hline \multirow{2}{*}{ Model } & Sum of & & & & \\
& Squares & df & Mean Square & F & Sig \\
\hline Regression & 13365.62 & 4 & 3341.405 & 4.93 & $0.005^{\mathrm{a}}$ \\
Residual & 16265.411 & 24 & 677.725 & & \\
Total & 29631.031 & 28 & & & \\
\hline
\end{tabular}

a: Predictors: (Constant), ROS, ROA, NP, EPS;

b: Dependent Variable: Growth.

The ANOVA table above shows that the F-value is 4.930 and the p-value is 0.005 which is very much less than 0.05 ( $95 \%$ level of significance), hence we reject the null hypothesis and conclude that the regression coefficients are significantly different from zero. This means that there is a linear relationship between growth 
and the independent variables.

The coefficient Table 11 below provides partial coefficients for the constant, EPS, NP, ROA and ROS. All the coefficients are significant at 95\% confidence level since their p-values (sig.) are less than 0.05 .

Table 11. Coefficients ${ }^{\mathrm{a}}$

\begin{tabular}{llllll}
\hline & \multicolumn{2}{c}{ Unstandardised Coefficients } & \multicolumn{3}{c}{ Standardised Coefficients } \\
Model & $\mathrm{B}$ & Std. Error & $\mathrm{B}$ & $\mathrm{t}$ & $\mathrm{sig}$ \\
\hline (Constant) & 104.943 & 6.987 & & 15.02 & 0 \\
EPS & 0.001 & 0 & 0.382 & 1.744 & 0.04 \\
NP & 0.002 & 0.002 & 0.223 & 1.404 & 0.017 \\
ROA & -1.425 & 1.045 & -0.223 & -1.364 & 0.042 \\
ROS & 1.031 & 1.267 & 0.181 & 0.813 & 0.024 \\
\hline
\end{tabular}

a: Depended Variable: Growth.

Hence the regression model is given by

$$
\text { Growth }=104.943+0.001 * E P S+0.002 * N P-1.425 * R O A+1.031 * R O S
$$

From the model we note that only the coefficient of ROA is negative which shows that there is a positive linear relationship between ROS, EPS, NP and Growth, the confirming linear and positive relationship between diversification and performance hence we confirm the positive linear relationship between diversification and firm performance as argued by Palich et al. (2000) and Miller (2006) in the linear model.

When focusing on the market based measures of performance (market price per share and share return), diversification also seems to be positive confirming the linearity and positivity of the diversification-performance linkage. This is contrary to Hitt (2006) who argued that expanded diversification leads to decreased performance as it increases costs of administering and governing and these outweigh the benefits. The authors also argued that firms diversifying outside their core business or competencies inherit increased costs that interfere with performance and this is contrary to the case of Innscor where unrelated businesses like Niloticus have been a tremendous success leading to its listing in the Zimbabwe stock Exchange as a separate entity delinked from the Group in 2011 as Pandenga holdings. The chairman of the Group had this to say in 2010 financial statements "Niloticus, the crocodile ranching operation could capitalize on its achievements to date by functioning as a stand -alone entity with renewed and specific focus".

\section{Discussion}

\subsection{Motives for Diversification}

The study also found that the conglomerates' desire to diversify was driven by the synergistic, growth, resource based and financial motives. Economies of scale and scope, shared skills, resources and competencies and risk reduction were some of the motives behind the adoption of diversification. This is in line with the arguments by Santalo and Beccera (2009).

\subsection{Diversification Strategies Adopted by the Zimbabwean Conglomerates}

The research established that the conglomerates employed different strategies for diversifying key among them being acquisition of associates and subsidiaries as opposed to outright acquisitions, joint ventures and strategic partnerships, for example 49\% stake in Irvine's Chicken by Innscor and 41.9\% stake of listed Ariston holdings by Delta. These approaches ensure continuity of the existing businesses, previous owners continue to provide a wealth of experience and business knowledge. Thompson and Strickland (2006) favour the approaches for the same reasons.

\subsection{Risks and Rewards Associated with Diversification}

The study found out that diversification is risky especially where the conglomerate grows and controlling activities becomes difficult. The findings tend to concur with Markides and Williamson (2007)'s view that related diversifiers may fail to exploit relatedness whilst unrelated diversifiers may fail to reap benefits due to administrative costs, coordination costs, business risk and management problems associated with different line of businesses being brought together. The rewards in terms of profitability, earnings, dividends and market share price compensate for the risk taken as shown in the study as they improved with the adoption of diversification. This is in line with Gary (2005) who points out that diversification leads to stability of cash flows and improved 
profitability.

\subsection{Relationship between Diversification and Performance for the Conglomerates}

For the conglomerates in the food and beverages sector in Zimbabwe, a positive linear relationship exists. The market power advantages, internal market efficiencies, shared resources advantages and financial advantages that diversified companies have over focused firm explain this relationship which was measured using turnover, profit and market measures in the study. The relationship depicts the Linear model (Miller, 2006).

\subsection{Diversification and Shareholder Value}

The study established that through diversification the conglomerates created value and justified their existence as they were able to build and leverage the unique resources to gain competitive advantage, increase profitability, market value of the companies ultimately improving shareholder value. Santalo and Beccera (2009) argued that value creation has been put at the top of the objectives which should guide firm strategy. Martin and Syrack (2003) found out that on average diversified firms increase shareholder value. They argued that on average diversification adds a premium to the value of the company thus improving shareholder value

The study concluded that the conglomerates had successfully used diversification as a long-term competitive strategy and had been able to establish a strong brand name and that it has used a combination of both related and unrelated diversification. Consistent with arguments by most researchers of the diversification-performance puzzle such as Daud et al. (2009), Syed and Rao (2004) and Thomas (2006), the research established that firm diversification was indeed related to accounting and market performance outcomes of a firm. The crux of the study centered on the answer of what is perhaps the most researched and yet unresolved question, how exactly does diversification affect firm performance?

After gathering empirical data, analyzing it and synthesizing models and theories from previous researchers, the research study indicated an important answer, which is diversification and performance were linearly and positively related. This confirms the linear model as explained by Palich et al. (2000) and Miller (2006). The benefits of diversification outweigh the costs hence performance increases or improves unconditionally contrary to Markides and Williamson (2007)'s view that as the firm increases diversification, it moves further away from its core business, and the benefits of diversification decline suggesting an intermediate model.

The conclusion also contradicts Hitt (2006) who argued that increased level of diversification increases performance up to a limit there after further diversification results in declining performance pointing to the inverted $u$ shaped model. The study also echoes the belief of the executives who thought diversification enhances firm value because it contributes to the improvement of the firm's risk-return profile. This confirms the Capital asset Pricing Model and the Markowitz Portfolio theory that diversification helps in reducing risk.

The conglomerates persistently created shareholder value, beat the market index and had a lower market volatility moreover we found that the performance as measured in terms of turnover growth, net profit, ROS, ROE and ROA increased in line with increase in diversification from 2000 to 2004. This is in agreement with Kuppswang and Villalonga(2010) who have argued in support of diversification improving shareholder value and creating wealth and high returns for investors. The conclusion contradicts Campa and Kedia (2002) and Ozbas and Scharfstein (2010) who pointed to diversification having a value destruction effect. Diversification is a competitive strategy which can bring positive results to the company if well implemented and aligned to the firm's vision and overall strategy as demonstrated by the conglomerates.

\section{References}

Aggarwal, R., \& Sanwick, A. A. (2003). Why do managers diversify their firms? Agency reconsidered. The Journal of Finance. http://dx.doi.org/10.1111/1540-6261.00519

Akbulut, M. E., \& Matsusaka, J. G. (2010). 50+ years of diversification announcements. The Financial Review, 45. http://dx.doi.org/10.1111/j.1540-6288.2010.00245.x

Andreou, P., \& Louca, C. (2010). Corporate diversification and firm value. SSRN Electronic Paper Collection.

Barney, J. (2006). Is there a diversification discount, diversification, payout policy and firm value. Management Journal.

Boston Consulting Group. (2006). How the world's top diversified companies produce superior returns.

Brealey, R. A., \& Meyers, S. C. (2008). Fundamentals of corporate finance (5th ed.). New York, NY: McGraw Hill.

Campa. J. M., \& Kedia, S. (2002). Explaining the diversification discount. The Journal of Finance. 
http://dx.doi.org/10.1111/1540-6261.00476

Collins, D. J., \& Montgomery, C. A. (2005). A corporate strategy: A resource based approach. New York, NY: Mc Graw-Hill

Collins, D. J., \& Montgomery, C. A. (2008). A corporate strategy: A resource based approach (2nd ed.). New York, NY: Mc Graw-Hill

Dastidar, P. (2009). International corporate diversification and performance: Does firm self selection matter? Journal of International Business Studies. http://dx.doi.org/10.1057/palgrave.jibs.2008.57

Daud, W., Salamudin, N., \& Ahnad, I. (2009). Corporate diversification and performance.

Delta Annual Reports. (1998, 1999, 2000, 2001, 2002, 2003, 2004).

Dimitrov. \& Tice. (2006). Corporate diversification and credit constraints, real effects across business cycle. The Review of Financial Studies. http://dx.doi.org/10.1093/rfs/hhj028

Dos Santos, M., Erranza, V., \& Miller, D. P. (2008). Does corporate diversification destroy value? Evidence from cross border mergers and acquisitions. Journal of Banking and Finance. http://dx.doi.org/10.1016/j.jbankfin.2008.07.010

Doukas, J., \& Kan, O. (2006). Does diversification destroy firm value? Journal of Finance.

Emms, E. E., \& Kale, J. R. (2006). Efficiency implications of corporate diversification: Evidence from micro data. Seatle University.

Gary, S. (2005). Implementation strategy and performance outcomes in related diversification. Strategic Management Journal.

Gould, M., \& Campbell, A. (2006). Designing effective organizations. London.

Herrman, C. (2009). Fundamentals of methodology.

Hitt, M. (2006). Corporate diversification and firm value: Evidence from post-1997 data. International Review of Finance.

Hitt, M., \& Hoskisson, R. (2005). Strategic management, competitiveness and globalisation: Concepts and cases (7th ed.).

Hoechle, D., Schmid, M., Walter, I., \& Yermarck, D. (2009). How much of the diversification discount can be explained by poor corporate governance? SSRN Paper. http://dx.doi.org/10.2139/ssrn.1341006

Hoskisson. \& Peng. (2005). Linking theory and context. Strategy Research in Emerging Economies.

Innscor Annual Reports. (1998, 1999, 2000, 2001, 2002, 2003, 2004).

Johnson, G., Scholes, K., \& Whittingtton. (2006). Exploring corporate strategy (7th ed.). New York, NY: Prentince Hall.

Kiymaz, H. (2006). The impact of announced motives, financial distress and industry affiliation on shareholders' wealth.

Kotler, P., \& Keller, K. L. (2006). Marketing management (12th ed.). Printincehall.

Kuppuswamy, V., \& Villalonga, B. (2010). Does diversification create value in the presence of external financing constraints? Evidence from 2007-2009 financial crisis.

Mackey, T. B. (2006). Essay on corporate diversification and firm value. The Ohio State University

Mackey, T. B. (2012). The value of diversification and opportunities foregone when re-investing the firm.

Maksmovic, V., \& Phillips, G. (2007). Conglomerate firms and capital markets. Handbook of Corporate Finance. http://dx.doi.org/10.1016/B978-0-444-53265-7.50022-6

Markides, C. C., \& Williamson, P. J. (2007). Related diversification, core competencies and corporate performance.

Martin, J. D., \& Sayrak. (2003). Corporate diversification and shareholders value: A survey of recent literature. Journal of Corporate Finance. http://dx.doi.org/10.1016/S0929-1199(01)00053-0

Masulis, R., Wang, C., \& Xie, F. (2007). Corporate governance and acquirer returns. The Journal of Finance. http://dx.doi.org/10.1111/j.1540-6261.2007.01259.x

Miller, D. J. (2006). Technological diversity, related diversification, and firm performance. Strategic 
Management Journal. http://dx.doi.org/10.1002/smj.533

Ozbas, O., \& Scharsfstein. (2010). Evidence on the dark side of internal capital markets.

Palich, L., Cardinal, L., \& Miller, C. (2000). Curvilinearity in the diversification-performance linkage, an examination of over three decades of research. Strategic Management Journal, 21(2). http://dx.doi.org/10.1002/(SICI)1097-0266(200002)21:2<155::AID-SMJ82>3.0.CO;2-2

Pindyck, \& Rubinfeld. (2005). Micro economics (5th ed.).

Santalo, J., \& Becerra, M. (2004). The effect of diversification on performance revisited:diversification discount, premium or both? Institutode de Empresa, Working Paper, Madrid.

Santalo, J., \& Becerra, M. (2008). Competition from specialized and the diversification performance linkage in. The Journal of Finance. http://dx.doi.org/10.1111/j.1540-6261.2008.01333.x

Santalo, J., \& Becerra, M. (2009). Theory of the firm for strategic management: Economic value analysis (1st ed.). United Kingdom: Cambridge University Press.

Stowe, J., \& Xing, X. (2006). Can growth opportunities explain the diversification discount? Journal of Corporate Finance. http://dx.doi.org/10.1016/j.jcorpfin.2005.05.001

Syed, A. M., \& Rao, N. V. (2004). Diversification, financing decisions and performance: An empirical review.

Thomas, D. E. (2006). International diversification and firm performance in Mexican firms. Is it a curvilinear relationship? Journal of Business Research. http://dx.doi.org/10.1016/j.jbusres.2005.08.008

Thompson, A. J., Gamble, A. A., \& Strickland, J. (2006). Crafting and executing strategy. The Quest for competitive advantage, Concepts and Cases.

Tongli, L., Ping, E. J., \& Chiu, W. K. (2005). International diversification and performance: Evidence from Singapore. Asia Pacific Journal of Management. http://dx.doi.org/10.1007/s10490-005-6418-4

Turner, I. (2005). Diversification: When and when not to? The Baybrooke Press.

Villalonga, B. (2004a). Diversification discount or premium? New evidence from BITS establishment level data. Journal of Finance. http://dx.doi.org/10.2139/ssrn.253793

Villalonga, B. (2004b). Does diversification cause "the diversification discount?" Financial Management Journal.

Wan, W. P. (2005). Country resource environments, firm capabilities and corporate diversification strategies. Journal of Business.

Wan, W. P. (2011). Resource based theory and corporate diversification: Accomplishments and opportunities.

Wright, M., Filatotchev, I., Hoskisson, R. E., \& Peng, M. W. (2005). Strategy research in emerging economies, challenging the conventional wisdom. Journal of Management Studies. http://dx.doi.org/10.1111/j.1467-6486.2005.00487.x

Yan, A. N., Yang, Z., \& Jiaco, J. (2009). Conglomerate investment under various capital markets.

\section{Copyrights}

Copyright for this article is retained by the author(s), with first publication rights granted to the journal.

This is an open-access article distributed under the terms and conditions of the Creative Commons Attribution license (http://creativecommons.org/licenses/by/3.0/). 